\title{
Evaluation of The Relationship Between Neutrophil to Lymphocyte Ratio and Renal Outcomes Patients with Chronic Renal Disease
}

\section{Kronik Böbrek Hastalığı Olan Hastalarda Nötrofil-Lenfosit Oranı ile Böbrek Sonuçları Arasındaki İlişkinin Değerlendirilmesi}

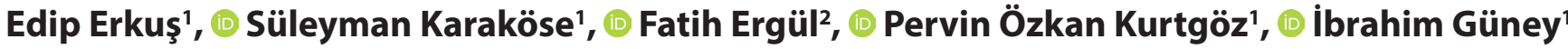 \\ ${ }^{1}$ Nephrology Department, University of Health Sciences, Konya Research and Training Hospital, Konya, Turkey \\ ${ }^{2}$ Internal Medicine Department, University of Health Sciences, Konya Research and Training Hospital, Konya, Turkey
}

\begin{abstract}
Aim: Regardless of the cause of renal disease, there is strong evidence that an acute and chronic proinflammatory condition exists in adults with chronic renal disease (CRD) and End Stage Renal Disease (ESRD) and that inflammation contributes to morbidity and mortality. In this study, we aimed to investigate whether neutrophil to lymphocyte ratio (NLR) and platelet to lymphocyte ratio (PLR) are associated with poor renal outcome (ESRD + Death) in patients with CRD.

Material and Method: 194 Turkish CRD (stage 3-5) patients who were regularly came to the nephrology outpatient clinic were enrolled to study. patients records were evaluated and groupped according to the renal status and mortality at the end of four years follow up time.

Results: During the follow-up period, 15 out of 194 patients died, renal replacement treatment began to 89 patients and remaning 90 patients were still followed as non-ESRD patients. When compared the patients with ESRD and who were still followed up as non-ESRD patients there was a statistically significant difference in male gender, follow-up time, Body mass index, Systolic blood pressure, Diastolic blood pressure, baseline eGFR, albumin, Hemoglobin, Calcium, Phosphorus, NLR, PLR and spot urine creatine ratio. NLR was as an independent risk factor in CRD patients for the progression of the disease and the poor renal outcome.

Conclusion: In conclusion, we demonstrated that NLR is an independent predictor of ESRD and poor renal outcome in CRD patients. Therefore, NLR measurement may be useful in predicting the progression of kidney disease in CRD patients.
\end{abstract}

Keywords: Neutrophil to lymphocyte ratio, platelet to lymphocyte ratio, chronic renal disease, progression
Öz

Amaç: Böbrek hastalığının nedenine bakılmaksızın, kronik böbrek hastalığı (KBH) ve Son Evre Böbrek Hastalığı (SDBY) olan yetişkinlerde akut ve kronik proinflamatuar bir durumun var olduğuna ve inflamasyonun morbidite ve mortaliteye katkıda bulunduğuna dair güçlü kanıtlar vardır. Bu çalışmada, CRD hastalarında nötrofil / lenfosit oranının (NLR) ve trombosit/lenfosit oranının (PLR) kötü böbrek sonucu (ESRD + Ölüm) ile ilişkili olup olmadığını araştırmayı amaçladık. Gereç ve Yöntem: Nefroloji polikliniğine düzenli olarak başvuran 194 Türk CRD (evre 3-5) çalışmaya alındı. Dört yıllık izlem süresi sonunda hasta kayıtları böbrek durumuna ve mortaliteye göre değerlendirildi.

Bulgular: Takip süresi boyunca 194 hastadan 15'i öldü, 89 hastaya renal replasman tedavisi başlandı ve 90 hasta halen ESRD olmayan hastalar olarak takip edilmektedir. ESRD olan hastalar ESRD olmayan hastalar ile karşılaştıııldığında erkek cinsiyet, takip süresi, Vücut kitle indeksi, Sistolik kan basıncı, Diastolik kan basıncı, başlangıç eGFR, albümin, Hemoglobin, kalsiyum, fosfor, NLR, PLR ve spot idrar kreatin oranı arasında istatistiksel olarak anlamlı bir fark vardı. NLR, CRD hastalarında hastalığın ilerlemesi ve kötü böbrek sonucu için bağımsız bir risk faktörü olarak bulundu.

Sonuç: Sonuç olarak, NLR'nin CRD hastalarında bağımsız bir ESRD ve kötü böbrek sonucu öngörücüsü olduğunu gösterdik. Bu nedenle NLR ölçümü, CRD hastalarında böbrek hastalığının ilerlemesini tahmin etmede yararlı olabilir.

Anahtar Kelimeler: Nötrofil / lenfosit oranı, trombosit / lenfosit oranı, kronik böbrek hastalığı, progresyon 


\section{INTRODUCTION}

The prevalence of chronic renal disease (CRD) is increasing as a result of the aging of the population and the increasing prevalence of diabetes mellitus (DM) and hypertension (HT). CRD is a growing health problem in the world because of its high cardiovascular event incidence. Even if the cause of kidney damage is eliminated, the risk of the cardiovascular event increases nephron loss results in adaptive hypertrophy and hyperfiltration in the surviving intact nephron. CRD progresses with glomerular sclerosis, proteinuria, hypertension, and other complex pathophysiological mechanisms up to the end-stage renal failure. ${ }^{[1-3]}$

Inflammatory processes play an important role in chronic diseases such as cardiovascular disease, cancer, chronic renal disease, type 2 diabetes and Alzheimer's disease. ${ }^{[4]}$ It is well known that chronic inflammation is present at low levels during CRD. ${ }^{[5]}$ The patients with CRD have higher pro-inflammatory cytokine levels and lower antioxidant and anti-inflammatory cytokine levels. ${ }^{[6]}$ Regardless of the cause of kidney disease, there is strong evidence that an acute and chronic proinflammatory condition exists in adults with CRD and EndStage Renal Disease (ESRD) and that inflammation contributes to morbidity and mortality. ${ }^{[7,8]}$ Furthermore, cytokines are involved in strengthening the inflammatory cascade and inducing kidney damage. This inflammatory response leads to the formation of profibrotic factors and the progression of CRD. ${ }^{[8,9]}$ Today it is uncertain which inflammatory marker is the best indicator of inflammation in CRD. C-reactive protein (CRP) is still the most commonly used indicator of inflammation despite many indicators such as erythrocyte sedimentation, IL-6, IL-8, IL-12, TNF-alpha, IL-33. .6, 10,11] $^{-1}$

Recently, neutrophil to lymphocyte ratio (NLR) and platelet to lymphocyte ratio (PLR) have begun to gain interest as a new marker in the assessment of inflammation. In this study, we aimed to investigate whether NLR and PLR are associated with CRD progression and poor renal outcome (ESRD and mortality) in patients with CRD.

\section{MATERIAL AND METHOD}

\section{Study design and setting}

This is a single-center observational retrospective study. The study was carried out with the permission of Sağlık Bilimleri University Konya Training and Research Hospital Medical Specialty Education Board (Approval no: 48929119/774/2805, Date: 01.08.2019).

\section{Selection of the participants}

We reviewed the data of 233 Turkish stage 3-5 CRD patients who were admitted to the nephrology clinic between January 2015 - May 2015 and followed up until July 2019. CRD-stages were determined with eGFR according to the Kidney Disease Improving Global Outcomes (KDIGO) guidelines. ${ }^{[12]}$

\section{Exclusion criteria}

The patients who were below 18 years old and have any cardiovascular disease (cerebrovascular disease, coronary artery disease...etc), malignancy and active inflammatory or an infective disease or using anti-inflammatory drugs were excluded from the study. The patients' records were retrospectively evaluated and a total of 39 patients who didn't come to the routine controls were excluded from the study.

\section{Data collection}

At the first admission beside the demographic data, CRD etiology, additional comorbidities (presence of DM and HT), systolic (SBP) and diastolic (DBP) blood pressure readings, body mass index (BMI), waist and hip circumference, smoking status were recorded. Serum urea, creatinine, eGFR (Modification of Diet in Renal Disease), MDRD, formula used to calculate the eGFR ${ }^{[13]}$, uric acid, sodium $(\mathrm{Na})$, potassium $(\mathrm{K})$, calcium (Ca), phosphorus $(\mathrm{P})$, albumin, ferritin, parathormone (PTH), total cholesterol, low-density lipoprotein (LDL), highdensity lipoprotein (HDL), triglycerides (TG), C-reactive protein $(\mathrm{CRP})$, hemoglobin $(\mathrm{Hb})$, neutrophils $(\mathrm{N})$, lymphocytes $(\mathrm{L})$, platelets (PLT), spot urine protein and creatine, spot urine protein to creatine ratio, venous blood gas values were recorded. European society of hypertension guidelines was applied during clinical blood pressure measurements. ${ }^{[14]}$ Waist and hip circumference were measured according to the recommendations of "The WHO STEPwise approach to noncommunicable disease risk factor surveillance".[15]

At the end of four years follow up period the results were evaluated and patients were grouped according to renal status. The primary endpoints were end-stage renal disease requiring renal replacement treatment (renal transplantation or hemodialysis or peritoneal dialysis) and death.

\section{Statistical analysis}

The standard statistical software package was used for statistical analysis (SPSS for Windows, version 22; SPSS; Chicago, IL, USA). Kolmogorov-Smirnov test was performed to determine whether the data were normally distributed or not. Since only the hemoglobin level is normally distributed so that it was given as mean \pm standard deviation. The other data were given as median (minimum-maximum). T-test was performed for normal data distributions and Man Whitney-U test for non-normal data distributions in paired comparisons. Cox-Regression (Backward Stepwise) analysis was performed to determine independent predictors of ESRD and poor renal outcome (ESRD+death).

\section{RESULTS}

During the follow-up period, 15 out of 194 patients died, renal replacement treatment began to 89 patients $(72$ underwent hemodialysis treatment and 17 underwent renal transplantation) and the remaining 90 patients were still followed as predialysis CRD (non-ESRD) patients. In our study, the main causes of renal diseases of the patients who completed the study were as follows; DM (58 patient, 29.9\%), HT (38 patient, 19.6\%), glomerulonephritis (GN) (20 patient, 10.3\%), polycystic kidney disease (PCKD)(20 patient, $10.3 \%)$, amyloidosis (4 patient, $2.1 \%$ ), chronic tubulointerstitial nephritis $(\mathrm{CTIN})(8$ patient, $4.1 \%)$, urological problems (9 patient, 4.6\%) and idiopathic(37 patient, 19.1\%). 
When compared the patients with ESRD and who were still followed up as non-ESRD patients there was a statistically significant difference in the male gender, follow-up time, BMI, SBP, DBP, baseline eGFR, albumin, Hb, Ca, P, PTH, DM NLR, PLR and spot urine creatine ratio (Table 1). The Cox-Regression analysis showed that the NLR was an independent risk factor for the progression of stage3-5 CRD patients to ESRD (Table 2).
There was a statistically significant difference between the patients with poor renal outcomes (ESRD+death) and nonESRD patients in respect of male gender, follow-up time, BMI, SBP, DBP, baseline eGFR, albumin, Hb, Ca, P, NLR, PLR and spot urine protein creatine ratio (Table 1). NLR was an independent risk factor in CRD patients for the poor renal outcome (ESRD+Death) in Cox-Regression analysis (Table 3).

\begin{tabular}{|c|c|c|c|}
\hline Variables & non-ESRD (n:90) & ESRD (n:89) & Poor renal outcomes (n:104) \\
\hline Age & $57.5(23-83)$ & $57(19-81)$ & $57(19-81)$ \\
\hline Gender (M/F) & $36(40 \%) / 54(60 \%)$ & 49 (55.1\%) /40 (44,9\%) A & 55 (52.9\%) /49 (47.1\%) B \\
\hline Smoking (Yes /No) & $7(7.8 \%) / 83(92.2 \%)$ & 13 (14.6\%) /76 (85.4\%) & 14 (13.5\%) /90 (86.5\%) \\
\hline Follow up time (month) & $49(25-52)$ & $19(1-50) A$ & $19(1-50) B$ \\
\hline $\mathrm{BMI}$ & $30.4(19.1-49.8)$ & $28.5(14-53) A$ & $28.5(13.5-53.1) B$ \\
\hline Waist circumference & $98(70-161) \mathrm{cm}$ & $96(55-165) \mathrm{cm}$ & $96(55-165) \mathrm{cm}$ \\
\hline SBP & $130(105-172) \mathrm{mmHg}$ & 142 (82-209) A mmHg & 142 (82-209) B mmHg \\
\hline DBP & 87 (47-117) mmHg & 94 (52-141) A mmHg & 94 (52-141) B mmHg \\
\hline DM (Yes/No) & 17 (18.9\%) /73 (81.1\%) & $30(33.7 \%) / 59(66.3 \%) A$ & 41 (39.4\%) /63 (60.6\%) B \\
\hline Baseline eGFR & $44.4(15.6-60.1) \mathrm{ml} / \mathrm{min} / 1.73 \mathrm{~m}^{2}$ & $22,3(11.6-48.8) \mathrm{A} \mathrm{ml} / \mathrm{min} / 1.73 \mathrm{~m}^{2}$ & $22.3(11.6-48.8) \mathrm{B} \mathrm{ml} / \mathrm{min} / 1.73 \mathrm{~m}^{2}$ \\
\hline Albumin & $4.1(1.6-4.7) \mathrm{g} / \mathrm{dl}$ & $3.9(1.8-4.5) \mathrm{A} \mathrm{g} / \mathrm{dl}$ & $3.9(1.8-4.5) \mathrm{B} \mathrm{g} / \mathrm{dl}$ \\
\hline $\mathrm{Hb}$ & $13.3 \pm 1.9 \mathrm{~g} / \mathrm{dl}$ & $12.1 \pm 0.2 \mathrm{~A} \mathrm{~g} / \mathrm{dl}$ & $12.1 \pm 1.8 \mathrm{~B} \mathrm{~g} / \mathrm{dl}$ \\
\hline Ürik asit & $7(2.8-11.1) \mathrm{mg} / \mathrm{dl}$ & $7(3.9-10.9) \mathrm{mg} / \mathrm{dl}$ & 7 (3.9-10.9) mg/dl \\
\hline $\mathrm{Ca}$ & $9.3(7.5-10.6) \mathrm{mg} / \mathrm{dl}$ & 8.7 (4.5-9.9) A mg/dl & 8.7 (4.5-9.9) B mg/dl \\
\hline $\mathrm{P}$ & $3.4(1.9-4.9) \mathrm{mg} / \mathrm{dl}$ & $3.8(2-14) \mathrm{A} \mathrm{mg} / \mathrm{dl}$ & $3.8(2.2-13.7) \mathrm{B} \mathrm{mg/dl}$ \\
\hline PTH & 113.3 (10.3-799) ng/L & $219.8(40-785) \mathrm{A} n g / \mathrm{L}$ & 219.8 (40-785) B ng/L \\
\hline Total cholosterol & $204(120-318) \mathrm{mg} / \mathrm{dl}$ & $210(94-415) \mathrm{mg} / \mathrm{dl}$ & $210(94-415) \mathrm{mg} / \mathrm{dl}$ \\
\hline LDL & $126(52-215) \mathrm{mg} / \mathrm{dl}$ & $135(48-278) \mathrm{mg} / \mathrm{dl}$ & $135(48-278) \mathrm{mg} / \mathrm{dl}$ \\
\hline HDL & $41(25-74) \mathrm{mg} / \mathrm{dl}$ & $38(22-93) \mathrm{mg} / \mathrm{dl}$ & $38(22-93) \mathrm{mg} / \mathrm{dl}$ \\
\hline TG & 150 (42-679) mg/dl & $159(40-634) \mathrm{mg} / \mathrm{dl}$ & $159(40-634) \mathrm{mg} / \mathrm{dl}$ \\
\hline CRP & $3.44(3.28-78.2) \mathrm{mg} / \mathrm{l}$ & $3.54(3-201) \mathrm{mg} / \mathrm{l}$ & $3.54(3-201) \mathrm{mg} / \mathrm{l}$ \\
\hline NLR & $2.17(0.92-7.32)$ & $2.72(0.84-8.81) \mathrm{A}$ & $2.72(0.84-8.81) B$ \\
\hline PLR & $0.12(0.06-0.32)$ & $0.14(0.05-0.38) \mathrm{A}$ & $0.14(0.05-0.38) \mathrm{B}$ \\
\hline Spot urine protein creatine ratio & $0.71(0.07-11.1)$ & $2.94(0.43-13.92) \mathrm{A}$ & $2.94(0.43-13.92) B$ \\
\hline \multicolumn{4}{|c|}{$\begin{array}{l}\text { A: } p<0.05 \text { as compared with non-ESRD B: } p<0.05 \text { as compared with non-ESRD } \\
\text { LDL: low density lipoprotein HDL: High density lipoprotein TG: Trigliserit BMI: Body mass index } \\
\text { SBP: Systolic blood pressure DBP: Diastolic blood pressure DM: Diabetes Mellitus Hb: Hemoglobin } \\
\text { NLR: Neutrophil to lymphocyte ratio PLR: Platelet to lymphocyte ratio }\end{array}$} \\
\hline
\end{tabular}

Table 2. COX-Regression model according to ESRD (HD + TX) in CKD (Backward Stepwise)

\begin{tabular}{|c|c|c|c|c|}
\hline \multirow{2}{*}{ Variables } & \multicolumn{2}{|c|}{ Model 1} & \multicolumn{2}{|c|}{ Model 7} \\
\hline & $\mathbf{P}$ & HR $(95 \% \mathrm{Cl})$ & $\mathbf{P}$ & HR $(95 \% \mathrm{Cl})$ \\
\hline Gender & 0.012 & $2.043(1.169-3.57)$ & 0.003 & $2.196(1.298-3.714)$ \\
\hline Baseline eGFR & $<0.001$ & $0.902(0.876-0.929)$ & $<0.001$ & $0.902(0.877-0.927)$ \\
\hline $\mathrm{P}$ & 0.022 & $1.282(1.036-1.588)$ & 0.036 & $1.205(1.012-1.435)$ \\
\hline DBP & 0.115 & $1.020(0.995-1.046)$ & 0.037 & $1.019(1.001-1.037)$ \\
\hline DM & 0.729 & $1.112(0.610-2.028)$ & & \\
\hline Albumin & 0.550 & $0.788(0.361-1.721)$ & & \\
\hline BMI & 0.250 & $0.971(0.924-1.021)$ & & \\
\hline PTH & 0.531 & $1.001(0.999-1.003)$ & & \\
\hline PLR & 0.067 & $0.004(0.000-1.484)$ & & \\
\hline
\end{tabular}




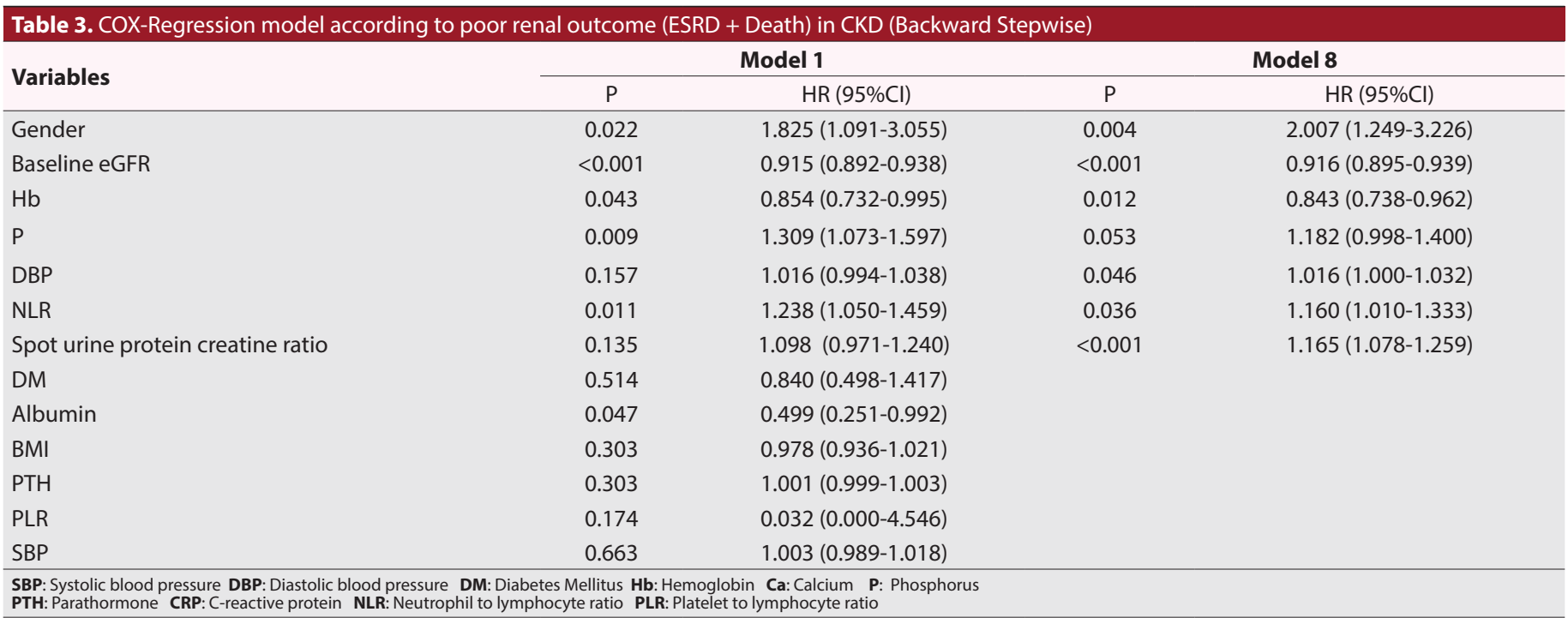

\section{Limitations}

The limitations of our study are the fact that it was a singlecenter study, patients who left follow-up for different reasons during the 4-year follow-up period. In addition, if the number of errors followed was higher, it would have added value to our study.

\section{DISCUSSION}

There are limited studies related to the NLR and renal progression in the literature. In this study, we demonstrated that the NLR is an independent indicator of progression to end-stage renal disease (ESRD) and poor renal outcome (ESRD+death) after 4 years of follow-up in patients with predialysis CRD. Renal progression was higher in patients with NLR $\geq 2.41$ than patients with NLR $<2.41$. In a study, with 105 patients, conducted by Koçyiğit et al. ${ }^{[16]}$ the patients with a decrease in renal clearance more than $5 \mathrm{ml} / \mathrm{min} /$ year classified as progressive and those with less than $5 \mathrm{ml} / \mathrm{min} /$ year decrease in renal clearance classified as non-progressive. The reflection of the inflammation shown with increased NLR predicts the progression of CRD to ESRD as an independent risk factor. In the same study, it was found that patients with stage 4 CRD with NLR $\geq 3$ showed a faster progression to ESRD than patients with NLR $<3$.

Predicting the progression of chronic renal failure is an important clinical issue. In recent years, some clinical studies have focused on identifying the predictive factors to slow down or even stop the progression of chronic renal disease. There is a common histological outcome in chronic renal disease independent from the etiology. Glomeruli, tubules and mesangial cells come into contact with plasma and interact with circulating inflammatory cells and regulate glomerular filtration rate. Neutrophils and macrophages contribute to glomerulosclerosis by producing inflammatory mediators. The mediators which were secreted from neutrophils cause the migration of more neutrophils and increase glomerular damage. As a result, glomerulosclerosis and decreased renal function are associated with the infiltration of the interstitium by inflammatory cells. ${ }^{[17,18]}$

Many studies have shown that risk factors for the progression of CRD are DM, lipid metabolism disorders, atherosclerosis, HT, smoking, the presence of inflammation indicators, obesity and male gender. ${ }^{[19,20]}$ Bash et al. ${ }^{[21]}$ reported that inflammation and homeostasis indicators are associated with the progression of chronic renal disease, regardless of the major traditional risk factors.

A study with 165 patients over 65 years which was conducted by Tatar et al. ${ }^{[22]}$ showed that CRD patients with increased NLR values have higher mortality and RRT initiation rates. Ryota Yoshitomi et al. ${ }^{[23]}$ conducted a study with 350 patients for seven years and reported that NLR level as an independent risk factor for renal disease progression in patients with CRD stages 1-4. In another study with 740 patients and 5 years follow up period showed that DM, young age and initial eGFR were independent factors in progression to ESRD in Coxregression analysis. ${ }^{[2]}$ In our study, we found that DM and baseline eGFR are independent predictors of ESRD and renal poor outcome (ESRD+mortality) in Cox-Regression analysis. In this study, we found that inflammation was associated with renal poor outcome independent of other causes. The relationship between NLR and renal progression is explained by the hypothesis that patients with higher NLR have more severe chronic inflammation. ${ }^{[25,26]}$ In our study, although CRP was not associated with ESRD and poor renal outcome, high $N L R$ value suggests increased inflammation in CRD. This finding shows us that $\mathrm{CRD}$ has inflammatory processes.

At present, there is no effective predictor for predicting the progression of CRD. Therefore, many researchers are trying to identify a predictive marker or find a model to assess the progress of CRD. Adiponectin, NT-proBNP, fibroblast growth factor 23, asymmetric dimethylarginine and apolipoprotein 
A-IV have been studied to evaluate the progression of CRD. ${ }^{[27-}$ ${ }^{31]}$ Although all these parameters have been shown to be useful in predicting CRD progression after adjustment for baseline renal function and other variables they are not applicable in clinical practice. Technical factors such as advanced laboratory requirements and excessive laboratory costs make the clinical use of these predictive markers difficult. In contrast, simply calculating the peripheral blood NLR is an easily accessible and applicable parameter for assessing progression in patients with CRD in clinical practice.

\section{CONCLUSION}

In conclusion, we demonstrated that NLR is an independent predictor of ESRD and poor renal outcome (ESRD+Death) in CRD patients. Therefore, NLR measurement may be useful in predicting the progression of CRD patients.

\section{ETHICAL DECLARATIONS}

Ethics Comittee Approval: The study was carried out with the permission of Sağlık Bilimleri University Konya Training and Research Hospital Medical Specialty Education Board (Approval no: 48929119/774/28-05, Date: 01.08.2019).

Informed Consent: Because the study was designed retrospectively, no written informed consent form was obtained from patients.

Status of Peer-review: Externally peer-reviewed.

Conflict of Interest Statement: The authors have no conflicts of interest to declare.

Financial Disclosure: The authors declared that this study has received no financial support.

Author Contributions: All of the authors declare that they have all participated in the design, execution, and analysis of the paper, and that they have approved the final version.

Acknowledgment: The authors have no commercial associations or sources of support that might pose a conflict of interest. All authors have made substantive contributions to the study, and all authors endorse the data and conclusions.

Conflict of interest: The authors declare that there are no conflicts of interest.

\section{REFERENCES}

1. Silverstein DM. Inflammation in chronic kidney disease: role in the progression of renal and cardiovascular disease. Pediatr Nephrol 2009:24:1445-52.

2. Yu HT. Progression of chronic renal failure. Arch Intern Med 2003:163:141729.

3. Jacobson HR. Chronic renal failure: pathophysiology. Lancet 1991:338:419-23.

4. Manabe I. Chronic Inflammation Links Cardiovascular, Metabolic and Renal Diseases. Circ J 2011;75(12):2739-48

5. Akchurin OM, Kaskel F. Update on inflammation in chronic kidney disease. Blood Purif 2015:39:84-92

6. Kalantar-Zadeh K. Inflammatory marker mania in chronic kidney disease: pentraxins at the crossroad of universal soldiers of inflammation. Clin J Am Soc Nephrol 2007:2:872
7. Hill PA, Lan HY, Nikolic-Paterson DJ, Atkins RC. ICAM-1 directs migration and localization of intersitial leukocytes in experimental glomerulonephritis. Kidney Int. 1994;45:32-42.

8. Lebleu VS, Sugimoto H, Miller CA, Gattone VH, Kalluri R. Lymphocytes are dispensable for glomerulonephritis but required for renal interstitial fibrosis in matrix defect-induced Alport renal disease. Lab Invest. 2008;88:284-92

9. Abbate M, Zoja C, Corna D, Capitanio M, Bertani T, Remuzzi G. In progressive nephropathies, overload of tubular cells with filtered proteins translates glomerular permeability dysfunction into cellular signals of interstitial inflammation. J AmSoc Nephrol. 1998;9:1213-24

10. Akchurin OM, Kaskel F. Update on inflammation in chronic kidney disease. Blood Purif 2015:39:84-92

11. Gungor O, Unal HU, Guclu A, et al. IL-33 and ST2 levels in chronic kidney disease: associations with inflammation, vascular abnormalities, cardiovascular events, and survival. PLoS ONE 2017:14(6):e0178939.

12. Kidney Disease Improving Global Outcomes (KDIGO) CKD Work Group (2013) KDIGO 2012 clinical practice guideline for the evaluation and management of chronic kidney disease. Kidney Inter Suppl 3:1-150

13. Levey AS, Coresh J, Greene T, et al. Chronic Kidney Disease Epidemiology Collaboration Using standardized serum creatinine values in the modification of diet in renal disease study equation for estimating glomerular filtration rate. Ann Intern Med 2006. Aug;145(4):247-54

14. Mancia G, De Backer G, Dominiczak A, et al. 2007 Guidelines for the management of arterial hypertension: The task force for the management of arterial hypertension of the European society of hypertension $(\mathrm{ESH})$ and of the European society of cardiology (ESC). Eur Heart J. 2007;28(12):1462-1536

15. WHO STEPS. Section 3: guide to physical measurements (Step 2). Geneva. 2008. Disponı'vel em:http://www.who.int/chp/steps/ Part3_Section3.pdf [Acessado em 28 June 2011

16. Kocyigit I, Eroglu E, Unal A, et al. Role of neutrophil/ lymphocyte ratio in prediction of disease progression in patients with stage-4 chronic kidney disease. J Nephrol. 2013;26:358-65

17. Klahr S, Schreiner G, Ichikawa I. The progression of renal disease. N Engl J Med. 1988;318:1657-66

18. Heinzelmann M, Mercer-Jones MA, Passmore JC. Neutrophils and renal failure. Am J Kidney Dis. 1999;34:384-99

19. Weinstein JR, Anderson S. The aging kidney: physiological changes. Adv Chronic Kidney Dis. 2010;17(4):302-7.

20. Fried L, Solomon C, Shlipak M, Seliger S, Stehman-Breen C, Bleyer AJ, et al. Inflammatory and prothrombotic markers and the progression of renal disease in elderly individuals. J Am Soc Nephrol. 2004;15:3184-3191

21. Bash LD, Erlinger TP, Coresh J, Marsh-Manzi J, Folsom AR, Astor BC. Inflammation, hemostasis, and the risk of kidney function decline in the Atherosclerosis Risk in Communities (ARIC) Study. Am J Kidney Dis. 2009;53:596-05

22. Tatar E, Mirili C, Isikyakar T, et al. The association of neutrophil/ lymphocyte ratio and platelet/lymphocyte ratio with clinical outcomes in geriatric patients with stage 3-5 chronic kidney disease. Acta Clin Belg 2016:71:221-6.

23. Yoshitomi R, Nakayama M, Sakoh $T$, et al. High neutrophil/lymphocyte ratio is associated with poor renal outcomes in Japanese patients with chronic kidney disease. Renal Failure 2019:41:1238-43.

24. Altunoren O, Akkus G, Tutuncu Sezal D, et al. Does neutrophyl to lymphocyte ratio really predict chronic kidney disease progression? Int Urol Nephrol 2019;51(1):129-37.

25. Wang X, Zhang G, Jiang X, et al. Neutrophil to lymphocyte ratio in relation to risk of all-cause mortality and cardiovascular events among patients undergoing angiography or cardiac revascularization: a meta-analysis of observational studies. Atherosclerosis. 2014;234:206-13.

26. Templeton AJ, McNamara MG, Seruga B, et al. Prognostic role of neutrophil-to-lymphocyte ratio in solid tumors: a systematic review and meta-analysis. J Natl Cancer Inst 2014;106:dju124. 
27. Kollerits B, Fliser D, Heid IM, Ritz E, Kronenberg F. MMKD Study Group. Gender-specific association of adiponectin as a predictor of progression of chronic kidney disease: the Mild to Moderate Kidney Disease Study. Kidney Int 2007;71:1279-86.

28. Spanaus KS, Kronenberg F, Ritz E, et al. Mild-to-Moderate Kidney Disease Study Group. B-type natriuretic peptide concentrations predict the progression of nondiabetic chronic kidney disease: the Mild-to-Moderate Kidney Disease Study. Clin Chem 2007;53:1264-72

29. Fliser D, Kollerits B, Neyer U, et al. Fibroblast growth factor 23 (FGF23) predicts progression of chronic kidneydisease: the Mild to Moderate Kidney Disease (MMKD) Study. J Am Soc Nephrol 2007;18:2600-8

30. Fliser D, Kronenberg F, Kielstein JT, et al. Asymmetric dimethylarginine and progression of chronic kidney disease: the mild to moderate kidney disease study. J Am Soc Nephrol 2005;16:2456-61.

31. Boes E, Fliser D, Ritz E, et al. Apolipoprotein A-IV predicts progression of chronic kidney disease: the mild to moderate kidney disease study. J Am Soc Nephrol 2006;17(2):528-36. 